\title{
Études/Inuit/Studies
}

\section{Franz Boas et les Inuit}

\section{Franz Boas and the Inuit}

\section{Ludger Müller-Wille}

Volume 32, numéro 2, 2008

Franz Boas et les Inuit

Franz Boas and the Inuit

URI : https://id.erudit.org/iderudit/038212ar

DOI : https://doi.org/10.7202/038212ar

Aller au sommaire du numéro

\section{Éditeur(s)}

Association Inuksiutiit Katimajiit Inc.

Centre interuniversitaire d'études et de recherches autochtones (CIÉRA)

\section{ISSN}

0701-1008 (imprimé)

1708-5268 (numérique)

Découvrir la revue

Citer ce document

Müller-Wille, L. (2008). Franz Boas et les Inuit. Études/Inuit/Studies, 32(2), 5-12. https://doi.org/10.7202/038212ar d'utilisation que vous pouvez consulter en ligne.

https://apropos.erudit.org/fr/usagers/politique-dutilisation/ 


\title{
Franz Boas et les Inuit
}

\author{
Rédacteur invité: \\ Ludger Müller-Wille*
}

Pour la seconde fois depuis sa fondation en 1977, Études/Inuit/Studies consacre un numéro à Franz Boas et sa relation avec les Inuit et l'anthropologie arctique. En 1984, les auteurs retraçaient l'héritage scientifique de Boas incluant l'anthropologie culturelle qui commença avec sa première recherche dans les années 1880. Dans le présent volume, les auteurs explorent de façon critique certains aspects des efforts scientifiques et de l'approche de Boas, en abordant les théories, concepts et méthodologies de ses études anthropologiques sur les Inuit.

L’année 2008 en est une d'anniversaires pour Franz Boas. Cette année marque le 150e anniversaire de sa naissance à Minden (Allemagne) le 9 juillet 1858; il mourut à New York le 21 décembre 1942. C'est aussi il y a 125 ans qu'eut lieu la première Année Polaire Internationale (1882-1883). Boas et son serviteur Wilhelm Weike suivirent les traces de celle-ci en demeurant avec des Inuit et des baleiniers américains et écossais au sud de Qikiqtaaluk (Terre de Baffin) en 1883-1884. De plus, en 20072009, se tient la 4e première Année Polaire Internationale. Enfin, il y a 120 ans que Boas (1888) publia son maintenant célèbre livre The Central Eskimo.

En 2008, la ville de Minden, son musée municipal, le Groupe de travail sur Franz Boas et le Centre de Recherche Interdisciplinaire de l'Université de Bielefeld ont organisé un certain nombre d'activités en Allemagne, incluant une exposition et un symposium pour honorer et célébrer Franz Boas et ses réalisations comme scientifique, anthropologue culturel et humaniste propageant et défendant les droits humains (voir Stadt Minden 2008). De plus, diverses publications ont paru en Allemagne et en Autriche, qui traitent des contributions de Boas aux sciences humaines et sciences sociales ainsi que des attitudes racistes qu'un nombre de scientifiques allemands et l'Allemagne nazie exprimèrent envers lui comme Juif dans les années 1930 et le début des années 1940 (Langenkämper 2008; Münzfreunde 2008; Pöhl et Tilg 2009; Schmuhl 2009). Dernièrement, la vie et les réalisations de Boas ont été étudiées de façon extensive par Douglas Cole (1999) et Norman F. Boas (2004). Les souvenirs de l'Arctique que Boas avait rédigés pour ses enfants à la fin des années 1890 ont aussi été édités (Boas 2007). Coïncidant avec les commémorations en l'honneur de Boas à Minden, le journal personnel que son serviteur Wilhelm Weike écrivit dans l'Arctique fut publié comme complément au journal personnel de Boas, écrit durant la même

Department of Geography, McGill University, Burnside Hall 705, 805, rue Sherbrooke Ouest, Montréal (Québec) H3A 2K6, Canada. ludger.muller-wille@mcgill.ca 
période (1883-1884) et publié dans les années 1990 (Müller-Wille et Gieseking 2008; Müller-Wille 1998 [1994]).

Le présent volume inclut quatre articles dans lesquels les auteurs ont choisi certains aspects spécifiques du travail de Boas avec les Inuit pour en discuter dans le contexte plus large du développement de la «science de l'humanité» —les sciences humaines, l'anthropologie et les sciences sociales-à la fin du 19e et au début du 20e siècle. Avec le temps, la personnalité scientifique et sociale de Boas a attiré l'intérêt de chercheurs en sciences sociales, qui ont réfléchi sur ses contributions et réalisations et les ont évaluées. Malgré de nombreuses évaluations critiques, il semble y avoir encore des angles du travail de Boas que la communauté scientifique juge importants et qui pourraient offrir une vision plus détaillée de son héritage.

Rainer Baehre se concentre sur «Le premier discours anthropologique sur les Inuit et l'influence de Virchow sur Boas» en analysant la création de l'image des Inuit en termes scientifiques durant le 19e siècle. Il fait référence à la définition de «race» de Rudolf Virchow qui eut un impact direct sur le jeune Boas et le début de son intérêt continu sur la culture et la race.

Dans «Évaluer la dimension éthique des recherches sur le terrain de Franz Boas dans l'Arctique et dans ses terrains anthropologiques subséquents», Friedrich Pöhl évalue la façon dont se déroulaient les premières études en sciences sociales. Il recense et assemble les sources archivistiques et publiées afin de sonder la position éthique de Boas et sa sollicitude lors de l'étude d'autres peuples et de leur culture. Pöhl aborde aussi de façon critique la manière obsessive avec laquelle les anthropologues et autres collectionneurs de cette époque obtinrent, souvent sans permission, de la «documentation physique» tels que des ossements humains et de la culture matérielle. Tout cela se faisait dans «l'intérêt» et la promotion de la science telle que comprise à ce moment-là.

En se penchant sur «La collaboration entre James Mutch et Franz Boas, 18831922» Kenn Harper fait découvrir à la communauté scientifique un élément particulier des méthodes de recherche de Boas. Il s'agit du «recrutement» d'un informateur indispensable et de toute une vie, sur lequel le scientifique compta pour évaluer l'authenticité des informations et données qu'il ne pouvait obtenir lui-même, pour diverses raisons. On a beaucoup écrit sur la relation de Boas et George Hunt, qui accomplit de telles tâches pour lui sur la Côte Nord-ouest (cf. Cole 1999; Boas 2004). Pourtant, le rôle de James Mutch dans le travail de Boas n'avait pas été pleinement évalué jusqu'à ce que Harper trouve de nouvelles données archivistiques et présente ici l'histoire de cette précieuse collaboration faite de respect mutuel.

Ce volume thématique se termine avec l'article de George Wenzel sur «Les établissements inuit de la région de Clyde durant la période de 'contact et exploration' (1820-1895)». Wenzel utilise les données démographiques que Boas établit pour les établissements inuit le long de la côte du détroit de Davis en 1883-1884 afin de 
discuter de l'évolution de cette occupation du territoire par les Inuit depuis le début du 19e siècle.

Ces contributions offrent une perspective diversifiée et une évaluation renouvelée des contributions de Boas qui ont été revisitée à maintes occasions. Elles jettent plus de lumière sur la personnalité intrigante de Boas, qui a façonné l'anthropologie culturelle dans toutes ses facettes.

Les volumes thématiques ont leur lot d'exigences particulières. Je voudrais donc remercier les quatre auteurs d'avoir accepté ce défi et soumis leurs textes. De plus, j'aimerais étendre mes remerciements à Murielle Nagy qui a guidé la rédaction de ces articles patiemment et avec compétence jusqu'aux dernières phases de leur publication.

\section{Références}

BOAS, Franz

1888 The Central Eskimo, Washington, Bureau of Ethnology, Sixth Annual Report of the Bureau of Ethnology 1884-85 [1888]: 399-669.

2007 Eskimo Story (Written for my Children), My Arctic Expedition 1883-1884, edited by Norman Francis Boas, Mystic, CT, Seaport Autographs Press.

BOAS, Norman Francis

2004 Franz Boas 1858-1942. An Illustrated Biography, Mystic, CT, Seaport Autographs Press.

COLE, Douglas

1999 Franz Boas, The Early Years, 1858-1906, Vancouver and Toronto, Douglas and McIntyre, Seattle and London, University of Washington Press.

\section{ÉTUDES/INUIT/STUDIES}

1984 Dans les traces de Boas - 100 ans d'anthropologie des Inuit / In Boas' Footsteps - 100 years of Inuit anthropology, 8(1): 3-101, 117-179.

LANGENKÄMPER, Jürgen

2008 Mindener Tageblatt - Serie Franz Boas, http://www.mt-online.de/boas.

MÜLLER-WILLE, Ludger (dir.)

1998 Franz Boas among the Inuit of Baffin Island 1883-1884, Journals and Letters, Toronto, Buffalo, London, University of Toronto Press [Franz Boas, Bei den Inuit in Baffinland 1883-1884, Tagebücher und Briefe, Berlin, Reinhold Schletzer Verlag 1994].

MÜLLER-WILLE, Ludger et Bernd GIESEKING (dir.)

2008 Bei Inuit und Walfänger auf Baffin-Land (1883/1884), Das arktische Tagebuch des Wilhelm Weike, Minden, Mindener Geschichtsverein. 
MÜNZFREUNDE MINDEN UND UMGEBUNG (dir.)

2008 Zum 150. Geburtstag, Franz Boas 9. 7. 1858 - 21. 12. 1942, Minden, Münzfreunde Minden und Umgebung.

PÖHL, Friedrich et Bernhard TILG (dir.)

2009 Wege einer antirassistischen Anthropologie Franz Boas, Kultur, Rasse und Sprache, Wien, LIT-Verlag.

SCHMUHL, Hans Walter (dir.)

2009 Franz Boas (1858-1942), Wissenschaft, Politik, Mobilität, Bielefeld, transcript Verlag.

STADT MINDEN

2008 Das Boas-Projekt, Minden 2008 (online at http://www.franz-boas.de). 


\section{Franz Boas and the Inuit}

\section{Guest editor: \\ Ludger Müller-Wille*}

For the second time during its existence since 1977 Études/Inuit/Studies has dedicated an issue to Franz Boas and his relation with the Inuit and arctic anthropology. In 1984, the contributing authors retraced Boas' scientific legacy including cultural anthropology that started with his first research in the 1880s. In this issue, the contributors explore critically specific aspects of Boas' scientific approach and efforts, touching upon theories, concepts and methodologies as they pertained to his anthropological studies of the Inuit.

The year 2008 is a year of anniversaries for Franz Boas. This year is the $150^{\text {th }}$ anniversary of his birth in Minden (Germany) on July 9,1858; he died in New York on December 21, 1942. Also it was 125 years ago that the first International Polar Year (1882-83) was carried out. Boas with his servant Wilhelm Weike followed in its footprints to stay with Inuit and American and Scottish whalers in southern Qikiqtaaluk (Baffin Island) in 1883-1884. Now during 2007-2009, the Fourth International Polar Year is held. And it was 120 years ago that Boas (1888) published his seminal book The Central Eskimo.

In 2008, the City of Minden with its municipal museum, the local "Franz Boas Working Group" and the Centre for Interdisciplinary Research at the University of Bielefeld organised a number of events in Germany that included an exhibit and a symposium to honour and celebrate Franz Boas and his achievement as scientist, cultural anthropologist and humanist propagating and defending human rights (see Stadt Minden 2008). Furthermore, a range of publications were issued in Germany and also Austria that focussed on Boas' contributions in the humanities and social sciences as well as on the racist attitudes that a number of German scientists and Nazi Germany expressed toward him as a Jew in the 1930s and early 1940s (Langenkämper 2008; Münzfreunde 2008; Pöhl and Tilg 2009; Schmuhl 2009). Lately, Boas’ life and his achievements have been treated extensively by Douglas Cole (1999) and Norman F. Boas (2004). Boas' own Arctic reminiscences written for his children in the late 1890s were edited recently (Boas 2007). Coinciding with the Boas commemorations in Minden, the complete Arctic diaries by Boas' servant Wilhelm Weike were presented as a complement to Boas' own diaries that were written at the same time in 1883-1884 and published in the 1990s (Müller-Wille and Gieseking 2008; Müller-Wille 1998 [1994]).

Department of Geography, McGill University, Burnside Hall 705, 805, rue Sherbrooke Ouest, Montréal (Québec) H3A 2K6, Canada. ludger.muller-wille@mcgill.ca 
This volume includes four articles whose authors have chosen specific aspects of Boas' work with the Inuit, discussing them in the larger context of the development of the "science of humankind"-humanities, anthropology and social sciences-at the end of the 19th and the beginning of the 20th century. Over time Boas' scientific and social personality has kept the attention of social scientists who have assessed and pondered his contributions and achievements. Despite numerous critical evaluations, there still seem to be angles to Boas' work that people in the research community deem important and which could provide more detailed insight into his continuing legacy.

Rainer Baehre concentrates on the "Early anthropological discourse on the Inuit and the influence of Virchow on Boas" by analysing the creation of the image of the Inuit in scientific terms during the 19th century. He makes reference to Rudolf Virchow's definition of "race" which had a direct impact on the young Boas and his emerging life-long focus on "culture and race."

Friedrich Pöhl evaluates the conduct of early active social research by "Assessing Franz Boas' ethics in his Arctic and later anthropological field work.” He reviews and collates both published and archival sources to probe Boas' ethical position and concern studying other peoples and their culture. Pöhl also discusses critically the obsession with, among others, anthropologists of that period who obtained, often without permission, "physical documentation" such as human remains and material culture. This was all carried out for "the sake" and the promotion of science as was understood during that time.

Looking at "The collaboration of James Mutch and Franz Boas, 1883-1922,” Kenn Harper makes the research community pointedly aware of a particular element in Boas' research methodology. This was the "recruitment" of a life-long competent and indispensable "informant" on whom the external scientist relied for access to authentic information and data that he, for whatever reason, could not obtain. Much has been written about Boas' relation with George Hunt who fulfilled such tasks for Boas on the Northwest Coast (cf. Boas 2004; Cole 1999). However, James Mutch's role in Boas' work had not been fully evaluated until Harper searched for new archival evidence and put together a lively story of this valuable relationship of mutual respect.

This thematic issue closes with George Wenzel's paper on "Inuit settlement in the Clyde area during 'contact-exploration' times (ca. 1820-1895)”. Wenzel utilises the demographic figures that Boas established for Inuit settlement along the coast of Davis Strait in 1883-1884 to discuss the evolution of Inuit occupancy since the early 19th century.

These contributions offer a diversified perspective and renewed evaluation of Boas' contributions that have been revisited over time. They all provide further insights into Boas' intriguing personality that has shaped cultural anthropology in its many facets. 
Thematic journal issues have their own demanding challenges. Therefore I would like to thank the four contributing authors that they accepted such challenges and submitted their papers to this issue. Furthermore, I would like to extend my thankfulness to Murielle Nagy who guided these papers patiently and competently through the final editorial stages.

\section{References}

BOAS, Franz

1888 The Central Eskimo, Washington, Bureau of Ethnology, Sixth Annual Report of the Bureau of Ethnology 1884-85 [1888]: 399-669.

2007 Eskimo Story (Written for my Children), My Arctic Expedition 1883-1884, edited by Norman Francis Boas, Mystic, CT, Seaport Autographs Press.

BOAS, Norman Francis

2004 Franz Boas 1858-1942. An Illustrated Biography, Mystic, CT, Seaport Autographs Press.

COLE, Douglas

1999 Franz Boas, The Early Years, 1858-1906, Vancouver and Toronto, Douglas and McIntyre, Seattle and London, University of Washington Press.

\section{ÉTUDES/INUIT/STUDIES}

1984 Dans les traces de Boas - 100 ans d'anthropologie des Inuit / In Boas' Footsteps - 100 years of Inuit anthropology, 8(1): 3-101, 117-179.

LANGENKÄMPER, Jürgen

2008 Mindener Tageblatt - Serie Franz Boas, http://www.mt-online.de/boas.

MÜLLER-WILLE, Ludger (ed.)

1998 Franz Boas among the Inuit of Baffin Island 1883-1884, Journals and Letters, Toronto, Buffalo, London, University of Toronto Press [Franz Boas, Bei den Inuit in Baffinland 1883-1884, Tagebücher und Briefe, Berlin, Reinhold Schletzer Verlag 1994].

MÜLLER-WILLE, Ludger and Bernd GIESEKING (eds)

2008 Bei Inuit und Walfänger auf Baffin-Land (1883/1884), Das arktische Tagebuch des Wilhelm Weike, Minden, Mindener Geschichtsverein.

MÜNZFREUNDE MINDEN UND UMGEBUNG (ed.)

2008 Zum 150. Geburtstag, Franz Boas 9. 7. 1858 - 21. 12. 1942, Minden, Münzfreunde Minden und Umgebung.

PÖHL, Friedrich and Bernhard TILG (eds) 
2009 Wege einer antirassistischen Anthropologie Franz Boas, Kultur, Rasse und Sprache, Wien, LIT-Verlag.

SCHMUHL, Hans Walter (ed.)

2009 Franz Boas (1858-1942), Wissenschaft, Politik, Mobilität, Bielefeld, transcript Verlag.

\section{STADT MINDEN}

2008 Das Boas-Projekt, Minden 2008 (online at http://www.franz-boas.de). 